\title{
Stimulating the Economy in an Era of Debt and Deficit
}

\section{JOSEPH E. STIGLITZ}

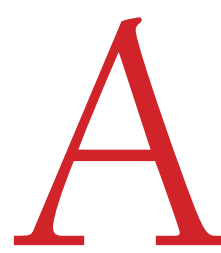

ny diagnosis of the current economic situation should focus on the fact that the shortfall between actual and potential unemployment is huge and that monetary policy has proven ineffective, at least in restoring the economy to anything near full employment.

Under these circumstances, the traditional economists' solution has been to advocate the use of fiscal policy-tax cuts and/or spending increases. There is an especially compelling case for increasing public investments because they would increase GDP and employment today as well as increase output in the future. Given

Joseph E. Stiglitz is University Professor at Columbia University, a Nobel laureate in Economics, and the author of Freefall: Free Markets and the Sinking of the Global Economy.

DOI: $10.1515 / 1553-3832.1897$ () De Gruyter low interest rates, the enhanced growth in GDP would more than offset the increased cost of government spending, reducing national debt in the medium term. Moreover, the ratio of debt to GDP would decrease and the ability of the U.S. economy to sustain debt (debt sustainability) would improve.

This happy state of affairs is especially likely given the ample supply of high-return investment opportunities in infrastructure, technology, and education resulting from underinvestment in these areas over the past quarter century. Moreover, well-designed public investments would raise the return on private investments, "crowding in" this additional source of spending. Together, increased public and private investment would raise output and employment in the short run, and increase growth and debt sustainability in the medium and long run. Such spending would reduce (not increase) the ratio of debt to GDP. Thus, the objection that the U.S. should not engage in such fiscal policies because of the high ratio of debt to GDP is simply wrong; even those who suffer from deficit fetishism should support such measures.

Critics of this standard Keynesian prescription raise two objections: (a) government is not likely to spend the money on high return investments, so that the promised gains will prove elusive and (b) the fiscal multipliers are small (perhaps negative), suggesting that the shortrun gains from fiscal policy are minimal at best. Both of these objections are easily dismissed in the current economic environment.

First, the assertion that government is incapable of making high return investments is just wrong. Studies of the average returns on government spending on investments in technology 
show extraordinarily high returns, with returns on investments in infrastructure and education returns well above the cost of borrowing. Thus, from a national point of view, investments in these areas make sense, even if the government fails to make the investments with the absolute highest returns.

Second, the many variants of the argument that the fiscal multiplier is small typically rest on the assumption that as government spending increases, some category of private expenditure will decline to offset this increase. ${ }^{1}$ Certainly, when the economy is at full employment and capital is being fully utilized, GDP cannot increase. Hence, under the circumstances, the multiplier must be zero. But today's economic conditions of significant and persistent resource underutilization have not been experienced since the Great Depression. As a result, it is simply meaningless to rely on empirical estimates of multipliers based on post-World War II data. Contractionary monetary policy is another reason why multipliers may be markedly larger now than they were in some earlier situations of excess capacity. In these cases, monetary authorities, excessively fearful of inflation, responded to deficit spending by raising interest rates and constraining credit availability, thus dampening private spending. But such an outcome is not inevitable; it is a result of policies, often guided by mistaken economic theories.

In any case, such an outcome is irrelevant today. This is because the Federal Reserve is committed to an unprecedented policy of maintaining near-zero interest rates through at least the end of 2014, while at the same time encouraging government spending. With interest rates at record lows and the Federal Reserve committed to keeping them there, crowding out of private investment simply will not occur. On the contrary, as I have noted, public investmentfor instance, in better infrastructure-is more likely to increase the returns to private investment. Such public spending crowds in private investment, increasing the multiplier.

Sometimes economists claim that consumers, worried about future tax liabilities in the wake of government spending, would contract their spending. However, the applicability of this notion (referred to as Ricardian equivalence) is contradicted by the fact that when George W. Bush lowered taxes and massively increased the deficit, savings plummeted to zero. But even if one believed in the applicabil- ity of Ricardian equivalence in today's economy, government spending on investments that increase future growth and improve the debt-toGDP ratio would induce rational to spend more today. Consumption would also be crowded in by such government expenditures, not crowded out.

Indeed, if consumers had rational expectations, the multiplier would increase even more in a long-lived downturn like the current one. The reason is that some of the money that is saved this year will be spent next year, or the year after, or the year after that-periods in which the economy is still well-below capacity. This increased spending will lead to higher employment and incomes in these later years. But if individuals are rational, the realization that their future incomes will be higher will lead them to spend more today. Deficit spending today crowds in not just investment, but also consumption.

Thus, a careful look at the current situation suggests that the impact of well-designed government programs will be to stimulate the economy more than is assumed to be the case in standard Keynesian models (which typically assume a short-lived downturn and yield a short

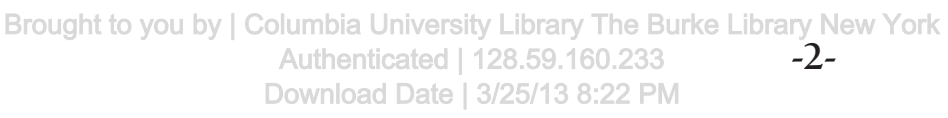

The Economists' Voice http://www.degruyłer.com/view/j/ev March, 2012 
run fiscal multiplier of around 1.5). Even in the current period, fiscal policy results in greater output increases because investment and consumption is crowded in, because: (a) the Federal Reserve is unlikely either to increase interest rates or reduce credit availability; (b) public investments are likely to increase the returns to private investments; and (c) rational consumers/ taxpayers may recognize that future tax liabilities will decline and that future incomes will rise as a result of these measures.

By the same token, in a long-lived recession such as this, forward-looking expectations provide an important cautionary note against popular deficit reduction packages that are "back loaded," with expenditure cuts that are slated to occur even two or three years down the line. If consumers are not confident that the economy will be healthy again at the end of that period, they will view such expenditure cuts as weakening the economy in the future. Consumers will thus be induced to save now to protect themselves against future economic contraction. Future social security cuts will similarly induce consumers to save more now, to ensure that they have funds for their retirement. Moreover, investors, anticipating a reduction in GDP in fu- ture years, may cut back investments now. In short, in a world of rational expectations, even expenditure cuts slated for the future can have contractionary effects today.

\section{WELFARE IMPROVING POLICIES THAT IMPROVE DEBT SUSTAINABILITY}

Tn the run-up to the current economic crisis, financial markets demonstrated an extraordinarily short-term perspective. The single minded focus on today's deficit, regardless of how the money is spent, is another manifestation of this short-sightedness. Government should take a longer-term perspective.

However, even if one focuses on debt sustainability, taking as given the constraint that government cannot increase its deficit in the short run, there are still policies that can stimulate the economy, increase our future growth potential, and improve our long-term-or even current-deficit position. In the standard economic model, the ratio of GDP to increased government spending produced by the "balanced budget multiplier" was unity. But if government raises revenues by taxing upper-income individuals who have high savings rates, and uses the funds for investments (or even unemploy- ment insurance), the balanced budget multiplier is much larger, by a factor of two or more. Converting saving to spending - at a time when the private return to investment appears to be so low and the public return to investment is so high - will be particularly productive.

The policy that I have just described both avoids an increase in today's deficit and improves debt sustainability over time because it leads to both an increase in GDP and a reduction in medium- to long-term national debt. The extra revenue generated by the increased growth and the reduced need for social expenditures to offset the effects of the downturn produce lower fiscal deficits.

This positive outcome is explained by the fact that different kinds of taxes and expenditures produce different multipliers. The typical short-run Keynesian multiplier of 1.5 discussed above is an average multiplier, which reflects the effect of increased government spending on consumers' marginal propensity to spend at all levels of the income distribution. However, the marginal propensity to consume out of unemployment benefits is very high; the marginal propensity to consume by the very rich is much, much lower. The result is that an extra 
dollar spent on unemployment insurance stimulates the economy a lot; an extra dollar "spent" on tax reductions for the rich reduces GDP by a much smaller amount. By pairing high multiplier expenditures with low multiplier tax increases, one can increase the balanced budget multiplier.

Moreover, it is worth noting that spending on unemployment insurance benefits, while potentially not as productive as spending on infrastructure investment, provides other benefits as well. For example, it is often argued that unemployment insurance discourages the search for employment, and thus introduces a market distortion. But just as multipliers differ in periods of high vs. low unemployment, so do the economic consequences of increased unemployment insurance. When there are only a limited number of jobs (right now, there are four job seekers for every job; at the worst point in the recession, there were seven), ${ }^{2}$ more search only increases the length of job queues. If higher unemployment benefits in a deep recession reduce wasteful search, with those who value a job least dropping out of the competition for the limited number of positions, then societal welfare is also improved.
DEFICIT REDUCTION-OR A WOLF'S AGENDA IN SHEEP'S CLOTHING?

$\mathrm{T}$ any case, the balanced budget multiplier is I but one example of welfare enhancing policies that maintain or even improve debt sustainability. For example, eliminating corporate welfare for coal, oil, and ethanol will eliminate a major distortion in the economy, improve the environment, and raise revenues. Similar benefits could be reaped by focusing on the "sale" of the country's national resources to corporations at prices below fair market value, and the procurement by Government of goods and services at prices above fair market value. The spectrum auctions showed how well-designed auctions could raise significant income for the Treasury, but we still have not applied the lessons to sales of most of the country's natural resources, some of which are almost given away. Likewise, while many deficit reduction proposals recognize that something should be done about corporate welfare-i.e., the large subsidies given to a variety of America's corporations, often hidden in special tax provisions-most of these proposals underestimate the pervasiveness of tax benefits for corporations, and their budgetary and economic costs.
That the deficit hawks ignore these realities suggests that they have another agenda: downsizing government and increasing the regressivity of our tax and expenditure system. ${ }^{3}$ If deficit reduction were really their objective, they would be focusing on the four developments that reversed the Clinton surpluses and mired us in the current situation. First, there were two large tax cuts that the country could ill afford. Second, there were two massively expensive wars, accompanied by unbridled increases in non-war-related defense expenditures-to the point that the U.S. accounts for around 50 percent of all global military expenditures. Third, Congress passed a much-needed prescription drug benefit under Medicare, but did it in a way that subsidized the drug industry, restricting the government's ability to bargain over drug prices. And fourth, there was the Great Recession, which eroded revenues and increased expenditures on unemployment and other social protection programs.

Ending the tax cuts, the wars, the gift to the drug companies-and most important, restoring the economy to its potential GDP-would go a long way to reversing our fiscal fortunes.

These simple prescriptions were not, however, at the center of the Bowles-Simpson Com- 
mission's recommendations. ${ }^{4}$ Instead, BowlesSimpson advocated austerity, at a time well before even the Federal Reserve thought the economy would be restored to full employment. Such austerity would almost certainly lower GDP and tax revenues. Indeed, it is curious that tax reductions would play any role in the recommendations of a Committee charged with improving the country's fiscal position (unless one believed in the discredited Reagan-era supply-side theories that played such a large role in getting the country into its current fiscal mess).

The Committee also failed to adhere to the principle of protecting the beleaguered middle class, whose income has decreased to levels below those of more than a decade ago. Growth in recent years has benefitted only the very top earners, who now take home a very large share of the nation's income. Because of this uneven income distribution, the imposition of modest tax increases on these top earners- particularly those with high unearned income-can raise large revenues. Yet the Committee's proposed reforms would have increased the effective tax rate on the middle class, thereby further weakening the real estate market (which was, of course, a precipitating factor in the economic crisis).
Policymakers' narrow focus on deficit reduction and debt sustainability has been misplaced. Our regressive and distortionary tax structure has received too little consideration, and when tax distortions do receive attention, too little thought is given to the distributive consequences of eliminating the middle class benefits and to the distortions associated with those that benefit the top. There is a broad sense across the country that the economic system-including our tax system-is unfair. In even more pragmatic terms, it makes no economic sense to tax those who work for a living at a higher rate than those who make a living from speculating. A fair tax system-taxing dividends and capital gains at the same rate as ordinary income-would both generate income and reduce a major distortion in the tax code.

\section{CONCLUDING COMMENTS}

The first priority of the country should be a I return to full employment. The underemployment of labor is a massive waste and, more than anything else, jeopardizes our country's future, as the skills of our young get wasted and alienation grows. As the work of Jayadev ${ }^{5}$ as well as the $\mathrm{IMF}^{6}$ convincingly shows, aus- terity in America will almost surely weaken growth. Moreover, as the work of Ferguson and Johnson ${ }^{7}$ shows, we should view with suspicion the claim (e.g. by Rogoff and Reinhardt) that exceeding a certain a debt-to-GDP ratio will trigger a crash. Even if this notion were true on average, the U.S. is not an average country. It is a reserve currency country, with markets responding to global instability-even when caused by the U.S.-by lowering interest rates. The U.S. has managed even bigger deficits. Unlike the countries of Europe, there is no risk that we will not pay what we owe. To put it bluntly, we promise to repay dollars, and we control the printing presses.

But a focus on the ratio of debt-to-GDP is simply economic nonsense. No one would judge a firm by looking at its debt alone. Anyone claiming economic expertise would want to look at the balance sheet-assets as well as liabilities. Borrowing to invest is different from borrowing for consumption. The failure of the deficit hawks to realize this is consistent with my earlier conclusion that this debate is not about the size of the deficit, but about the size of the government and the progressivity of the tax system.

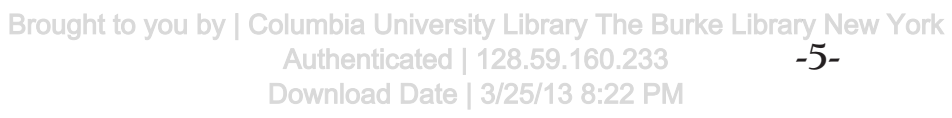

The Economists' Voice http://www.degruyłer.com/view/j/ev March, 2012 
Letters commenting on this piece or others may be submitted at http://www.degruyter.com/ view/j/ev?tab=services

\section{NOTES}

1. The fiscal multiplier effect refers to the fact that when the government spends money, the newly spent money recirculates, increases GDP over and over again, except for leakages-money that flows out of the system to government or to foreigners. Typically, claims that the fiscal policy multiplier is small are based on the assumption that private expenditure will decline, rather than large leakages out of the system.

2. ibid

3. My hypothesis that the deficit hawks have an alternative agenda is also consistent with their astounding advocacy of policies that mix tax cuts with matching expenditure reductions, while failing to acknowledge that such policies generate a negative balanced budget multiplier. Such proposals are even more damaging when there is a reduction in progressivity of the tax and expenditure system.

4. The National Commission on Fiscal Responsibility and Reform (often called Bowles-Simpson/ Simpson-Bowles from the names of co-chairs Alan Simpson and Erskine Bowles; or NCFRR) is a Presidential Commission created in 2010 by President Barack Obama to identify policies to improve the fiscal situation in the medium term and to achieve fiscal sustainability over the long run. The report is available at http://www.fiscalcommission.gov/sites/ fiscalcommission.gov/files/documents/TheMomentofTruth12 1 2010.pdf
5. Arjun Jayadev, forthcoming, "Distribution and Crisis: Reviewing some of the Linkages" Handbook on the Political Economy of Crisis," G. Epstein and M. Wolfson, editors.

6. Andrew G. Berg and Jonathan D. Ostry (2011) "Inequality and Unsustainable Growth: Two Sides of the Same Coin?" IMF Staff Discussion Note, SDN/1108, April, available at http://www.imf.org/ external/pubs/ft/sdn/2011/sdn1108.pdf (accessed October 20, 2011)

7. ibid

\section{C}

